\title{
XLVII. Zoological notices
}

\section{Mr. John Edward Gray}

To cite this article: Mr. John Edward Gray (1824) XLVII. Zoological notices, Philosophical Magazine Series 1, 63:312, 274-277, DOI: $10.1080 / 14786442408644507$

To link to this article: http://dx.doi.org/10.1080/14786442408644507

$$
\text { 曲 Published online: } 27 \text { Jul } 2009 .
$$

Submit your article to this journal

LII Article views: 5

Q View related articles $\asymp$ 


\section{$[274]$}

XLVII. Zoological Notices. By Mr. John Euward Gray.

\section{On the Characters of Zoophytes.}

SINCE the discovery by Ellis, that the corals and other zoophytes were the houses of animals, there appears to have existed in the greater number of persons a considerable difficulty to draw the line of demarcation between them and the Marine Algæ; but this difficulty must have arisen from the consideration of them as animals themselves, and not as the houses of animals, in the same manner as sbells are to the Mollusca. For in the consideration of them in the latter point of view, it is impossible that they can contain the animals without a space to hold them; this space, or at least its mouth, as the animals are always regularly radiated, is constantly regular and mostly symmetrical; so that let the structure be either a simple tube, or many tubes close together or separated by the intervention of cretaceous matter forming a plantlike structure, they always terminate in a regular mouth. Whereas marine plants are formed entirely of cellular structure, which is condensed on the surface to the form of a cuticle (which is sometimes, as in the Sponges, mucilaginous), and they very seldom have any apertures on their surface, or, if they have, these are always irregular.

Now since Silex is generally allowed to be found on the surface of many Monocotyledones, and Tabasheer in the joints of the Bamboo, why should not chalky matter be found in Alge? Indeed it is to be seen on the surface and internal structure of several Thalassiophytes which have never been considered as zoophytes.

Therefore I should consider none of the marine plant-like bodies to be of animal formation, unless cells could bediscovered opening on their surface with regular apertures; and consequently there is no reason why the genera Corallina, Dichotomaria, $P \mathcal{C}-$ nicillus, and Flabellaria, of Lamarck, and perhaps even Nullipora of Cuvier, should not be placed with the Alga. The first of these I have ventured to remove to their ancient habitation, on account of their bearing tulercles very similar in appearance to those of many of Ceramiadce or marine confervæ; and the first section of Flabellaria, especially Flabcllaria pavonia of Lamarck, bears a very great affinity to, as the abovenamed author justly observes, if it does not actually belong to the same genus as the Ulva pavonia of Linnsus, which Draparnaud the elder has formed into a genus under the name of Zonaria. This affinity induced me to place the Coralline so close to the Zonarice, in my father's Natural Arrangement of British Plants. 
On Gadinia, a new Gemus of Patelloid Shells.

\section{Gadinia.}

Testa univalvis, non symmetrica, oblique conica ; vertice obtuso, subpostico. Apertura suborbiculata, irregularis ; cavitas simplex, sulco in latere dextro prope limbum anticum, impressionis muscularis ; impressio muscularis elongata, arcuata, submarginalis.

Animal ignotum.

This genus is instantly to be distinguished by the peculiar groove, which is formed, there is little doubt, by the tube that directs the air to the respiratory cavity of the animal, with which unfortunately we are unacquainted.

I have only observed one species, which, having been called Le Gadin by Adanson, I have consequently named

1. Gadinia afra. Testa oblique conica, alba, radiatim striatocostata subsquamosa; vertice sublævi; marginibus crenulatis.

Patella afra. Gmelin 3715 ! Dillwyn. Rec. Shells, ii. 1046 !

Patella n. 1. Schroeter. Einl. ii. 441.

Le Gadin. Adanson Senegal. 33. t. 2.f. 4 !

Icon. Gaulter t. 9. f. 6. Martini i. 93 t. 5. f. 34.

Inhabits Coast of Africa. Coast of Cape Manuel and the Island of Goree. Adanson.

Shell white univalve not symmetrical, obliquely conical with an obtuse vertex placed towards the hinder part, rayed with many rather scaly rib-stria diverging from the apex; the aperture is nearly orbicular, crenulated, sometimes slightly extended, on the right anterior lateral portion, just over the groove; the cavity is simple, concave with a slight groove near the front part of the right limb of the horse-shoe shaped, sub-marginal muscular impression.

Length and breadth about $\frac{1}{2}$ inch.

This shell is not uncommon in collections, and may be confounded with Siphonaria; but in that genus the groove is placed in the muscular impression, and divides it into two portions. I had, in a paper which it was my intention to have published the beginning of last year, called the latter genus Liria, believing the Patella tristensis of Dr. Leach to be Le Liri of Adanson and consequently the Patella perversa of Gmelin; but as Mr. G. Sowerby has lately published this shell with two or three others under the generic name of Siphonaria, it should be adopted.

He has however in my opinion fallen into the common error M $\mathrm{m} 2$ 
of modern conchologists, of making too many species; for I have good reason to believe that all the specimens that he has figured, except S. tristensis, (with several varieties in the British Museum), belong to one species, for which I propose the name of S. radiata. There is, I believe, another species found in the United States, which Mr. Say has described under the name of Patella alternata, which, should my surmises be correct, will be a curious circumstance, as the other two species are confined to the African seas.

\section{Marisa intermedia.}

\section{On some new Species of Ampullariadce.}

M. testa subdiscoidea, lævi, pallide olivacea, lata fusco-unifasciata; spira concaviusculo-plana, apice subprominente acuto; columella (axi) concavo-conica effusa.

Inhabits Brazils. Mus. J. Sowerby, Nostr.

Shell nearly discoidal, smooth pale green with a broad brown central spiral band, spire very slightly concave, nearly flat, apex slightly prominent acute, columella (axis) conical concave effused exhibiting most of the whorls; aperture narrow, half as broad again as the last whorl but one, peristome simple slightly reflexed in front, axis $\frac{1}{2} \frac{1}{0}$, diameter 1 inch.

Marisa is the name which I propose for a genus of shells which has been confused with Ampullaria, but which differs from it in having a horny operculum and simple peristome.

This shell is very interesting as being intermediate between Ampullaria Cormu arietis and A. effusa of Lamarck ; and I believe that Mr. Swainson had confounded it with the former species when he observed that Mr. G. B. Sowerby had discovered the operculum of that species, for I have reason to think that my specimen is the fellow to the one in Mr. Sowerby's collection, as he presented me with it at the time he bought them; so that the operculum of that species is still a desideratum, although I have no doubt that it is furnished with one.

This shell is instantly to be distinguished from the two former species by the flatness of the spire, and the size of its umbilicus; and the two specimens that $I$ have seen have only one broad band, whereas the other species have five or six narrow ones, but this may be subject to variations.

The controversy that has arisen regarding the situation of the $M$. Cornu arietis is an illustration of one of the numerous errors between analogy and affinity; for there is no more reason for placing it amongst the Planorbes on account of its subdiscoidal form, than there would be for arranging the Bats with the Birds on account of their fluttering through the air. As to 
the assumed absence of the columella, it is no more wanting in this than in any other species of the genus.

In fact, it only differs from them in the size of the space between the whorls; and if it is to be placed in the latter genus on that account, several other shells, such as the Staircase Trochus, \&c. must be also added to it. I am the more astonished at the controversy, as one of the parties has travelled through the Brazils, where this genus is found, and where he might have learnt that the Marise have gills and breathe air through the medium of water; and every English conchologist knows that the Planorbes on the other hand breathe, by means of a closed bag, fiee air, which they come to the surface to procure. Consequently these two genera cannot have any affinity with each other, and their resemblance must be purely analogical, and few persons would be inclined to place genera with such different animals side by side. Again, I do not know any of the Planorbes to be banded, as is the case with most of the Ampullariade, and colour is not an unimportant adjunct to the natural arrangement of organized bodies, as most zoologists and botanists are well aware.

Bithinia lutea.

B. testa ovata, lævi, pallide lutea, pellucida; anfractibus quatuor, convexis ; apice obtusa ; columella perforata.

Ditches, East Indies. Mrs. F. Gray.

Shell ovate, smooth, pale yellow, pellucid; the whorls four, rather convex, the sutures distinct; the apex obtuse as if the first whorl was broken off; the axis with a narrow deep perforation, axis $\frac{3}{10}$, diameter $\frac{5}{20}$ of an inch.

Bithinia is a generic name proposed by Mr. Prideaux for the small ovate species of Ampullariada which have a shelly operculum and slightly thickened peristome, of which Helix tentaculata may be considered the type.

Bithinia pusilla.

B. testa ovata, lævi, alba, hyalina, anfractibus quatuor, convexis ; apice subobtusis ; columella imperforata.

Ditches, East Indies. Mrs. F. Gray.

Shell ovate, smooth, white, hyaline, with four convex whorls divided by very distinct sutures, and rather obtuse at the apex; the axis is imperforated, axis $\frac{3}{20}$, diameter $\frac{2}{10}$ of an inch.

I have transmitted both these latter species to the Baron Ferussac, who declares them to be as yet undescribed and new to him. 